\title{
10 \\ WRITING A DICTIONARY OF WORLD BIOGRAPHY
}

\author{
BARRY JONES
}

For more than 60 years I have worked in short bursts on a major project, known in its current iteration as the Dictionary of World Biography (DWB). It reflects my preoccupation, even obsession, about making sense of the world to myself and sharing my insights to others. The work, inevitably, is highly personal, even semi-autobiographical, projecting my involvement in politics, teaching history, extensive travel, and absorption in music, literature, the arts, religion, philosophy, ethics, and the relief of human suffering, through decades of work with a disaster relief organisation and campaigns to reduce blindness. It reflects the influence of Bertrand Russell, whom I observed in Melbourne at close quarters as a student in 1950. He said: 'Three passions, simple, but overwhelmingly strong, have governed my life: the longing for love, the search for knowledge, and unbearable pity for the suffering of mankind'.

Produced in various incarnations since 1981, the $D W B$ began to be published by ANU E Press (later ANU Press) in 2013. What began as a personal project has become a popular reference work. The DWB is not objective; biased in several ways, it is nevertheless accurate and well researched. Unlike many national biographical dictionary projects, it includes living as well as dead subjects. Long, at over 900 printed pages, I aimed to ensure it had an engaging, readable style. In a world of Wikipedia and large-scale collaborative national biographical dictionary

1 Bertrand Russell, Autobiography, with an introduction by Michael Foot (London and New York: Routledge, 1998), 9. 
projects there is still a place for a sole-authored dictionary of world biography. It has been proposed that the work be renamed Barry Jones' Dictionary of World Biography, and for years I resisted the idea because it seemed egotistical. But it seems quite appropriate now, given the work's personal and idiosyncratic nature, when alternative sources of information, great masses of it, are available on Wikipedia and a range of websites. The project calls into question, perhaps, some of the standard templates of biographical dictionaries-above all, the national perspective-and shows how varied and popular the genre is.

\section{Background of the Dictionary of World Biography}

In the mid-1950s I had been puzzled that no comprehensive biographical dictionary was available in paperback at a modest price. I determined to fill the gap. As a university law student I had been concerned that so many contemporaries had either a sketchy, or nonexistent, grasp of recent political history, let alone familiarity with great composers, or philosophers, or of discoverers in other disciplines, such as medicine. References to my heroes Bertrand Russell, Albert Schweitzer, or Albert Einstein drew a blank. Important and controversial Australians, such as Billy Hughes, John Thomas Lang, or Percy Grainger, were forgotten, or had never been known. I was trying to pursue the concept of 'the abundant life' and I felt pained that so many had no access to the unfamiliar. If they knew nothing of Bach or Michelangelo, they were missing something significant. I always planned that my $D W B$ would be more than a collected list of names, dates, and places. It was always intended to provide a hook, something that encouraged the reader to pursue the subject: in effect, sharing my enthusiasms.

It was hubris of a high degree to embark on something so ambitious for my first book, but I could see that there was a gap to be filled. The two generally available major works in the field-Chambers Biographical Dictionary and Webster's (later Merriam-Webster's) Biographical Dictionary—both had significant weaknesses. One was too British, with a poor representation of names outside of Europe (a deficiency corrected somewhat in later editions), and the second, while far more comprehensive, offered short entries, little more than concise lists of dates, offices held, 
or works produced, providing no, or rare, interpretation or context. Both were heavy and expensive, while I planned a book that students could carry around.

While I was teaching history and literature at Dandenong High School, I typed away furiously on my old Olivetti. I retain three bound volumes of my first draft bearing the final date of 5 May 1959, when I was only 26. The text runs to 837 foolscap pages, with about 430,000 words and 6,000 entries. Amendments and new entries over the next 20 years were pasted in. Much of the original text survives in later, much expanded, editions, now about double in length.

Several significant elements were integral to my project. It proved to be an important teaching tool, giving me confidence and communicating enthusiasm, making sense of the great religions, the Renaissance, Reformation, revolutions in America, France, Russia, and China, World Wars I and II, Communism and Fascism, Australian Federation, opening up scientific method, philosophy, music, architecture, and the visual arts. Another factor was the development of my collection of autographed letters and documents. I bought many specimens of subjects who were out of reach (Napoléon, Darwin, Lincoln, Dickens, Wagner, Queen Victoria, Tolstoy), but if I sent copies of my draft entries to those who were living - for example, Igor Stravinsky, Ezra Pound, Oskar Kokoschka, E. M. Forster, Francis Crick, or Noam Chomsky-I was likely to receive a significant reply. This was an incentive to get it right, although I did not invariably accept their self-assessment.

Between 1960 and 1968, while I was refining the $D W B$, I appeared 208 times on the television quiz show Pick-a-Box, far more than any other contestant. This conferred an immediate, uncomfortable, and at times embarrassing, celebrity on me, comparable to minor sporting heroes. Some saw me as a role model, others as an irritating, overconfident, overexposed know-all. The work on my first draft was a central factor in my success on Pick-a-Box. I was also heavily involved in Labor Party politics, research, and public advocacy on many causes, especially the abolition of capital punishment, and educational reform. So I read voraciously on the history of criminal law, and thought endlessly about creativity and exposure to the arts. 
I worked on my project on and off for decades. While largely relying on instinct, I would have backed my own judgment on the choice of names, and their relative length, against all comers. My selections were influenced by my constant reading of biographies, noting how often a particular name would have multiple references in indexes in a random sample of books about, say, twentieth-century politics. If Winston Churchill was in all of them he received a far longer entry in the DWB than, for example, his Labour contemporary Herbert Morrison, quite apart from Churchill's intrinsic interest and versatility as historian and painter. However, I could check my judgment objectively by referring to the Biography Index, a cumulative list of biographical material in books and magazines, published quarterly by the H. W. Wilson Company, New York. (This was long before the internet revolutionised the ranking of name frequency.) I set my entries in the broad context of history, pointed to relationships and influences between major characters and their times, and challenged entries in other reference books. I was making judgments all the time. I included cross references ${ }^{*}$ ) and a bibliography to encourage discursive reading.

I wrote to Penguin Books in Harmondsworth, London, and received a thoughtful and encouraging letter from A. S. B. Glover, a classical scholar and editor. In January 1961 I took my first draft to London and arranged a meeting with Penguin Books. Charles Clarke, a senior editor, began by reviewing my entry on the psychiatrist Carl Gustav Jung, and this impressed him enough to offer me a contract and a generous advance. Unfortunately, soon after the contract was signed, Clarke left Penguin for the Tavistock Institute, and years of uncertainty and confusion followed. There were deep divisions within Penguin Books, and very strong differences of opinion about whether they should be publishing general reference books at all. After both Glover and Clarke had departed, the project drifted for years and there was obvious concern about the credibility of a young antipodean author, of whom they knew nothing. An attempt to break up the text and send it off to specialist editors ended in high farce. In 1969 I received the first page proofs only to find that many entries in the letters B (Bach, Beethoven, Brahms, Bruckner, Byrd) and $\mathrm{H}$ (Händel, Haydn, Heine, Hemingway, Herodotus, Homer, Horace, Victor Hugo) had gone missing. Confucius and Goya had dropped out too. In 1977 the project was abandoned, and Penguin paid me off, but it was soon taken up by Macmillan. 
The Macmillan Dictionary of Biography was published in London in 1981 and by Rutledge (1981) and the St Martin's Press (1986) in New York. In 1994 a much expanded edition, under the title Dictionary of World Biography, was published by Michael Wilkinson at Information Australia, in association with the Age, Melbourne. In 2013 ANU E Press produced the work, revised and rewritten again, in paperback and online. Then Michael Wilkinson published a handsome hard-cover version in 2016 in conjunction with ANU Press.

\section{Sourcing Entries}

Inevitably, my work is semi-autobiographical, reflecting my own experience, understanding, attempts to grasp a world view, dealing with diversity, and trying to neutralise prejudice. I was always a very rapid and-more important-efficient reader and over the decades I have consumed thousands of books, including novels, biographies, plays, and poetry, as well as being an assiduous visitor to art galleries and museums, a modest collector of art works and archaeology, and a concert hall habitué. Travel was also a very important factor. In Paris in May 1958, I had witnessed the collapse of the Fourth French Republic, and this, followed by years in France as Australia's representative to the United Nations Educational, Scientific and Cultural Organization (UNESCO: 1991-95) and the World Heritage Committee (1995-96), fuelled my interest in French history, especially the French Revolution, art, music, politics, science, and architecture. I have visited France more than 40 times. My obsessions included revolutionary and political history, Montaigne and Pascal, Debussy and Ravel, Proust, films, churches and cathedrals, Cavaille-Coll organs, menhirs and dolmens in Brittany, and prehistoric cave art in the Dordogne. Entries on de Gaulle, Mitterrand, Chirac and Macron, Simone Veil and Viollet-le-Duc have been enlarged as I better understand complexities.

My book Sleepers, Wake!: Technology and the Future of Work (1982) reflected my growing preoccupation with the information technology revolution; I observed the impact of globalisation through work with the Organisation for Economic Co-operation and Development; saw the collapse of the Soviet Union at first hand; was an early advocate of international action on global warming; and became involved with medical researchers. As science minister and thereafter I had close contact with eminent 
scientists: Burnet, Medawar, Crick, Nossal, Doherty, Oliphant, Perutz, Denton, Miller, Stanley, May, and Williamson. I revised interminably, after discussions with Isaiah Berlin, Michael Tippett, Karl Popper, Henry Moore, Ernst Gombrich, and Benoît Mandelbrot.

I was exhilarated by the challenge to rethink and rewrite my positions on great historical figures after many years of deep reading, travel, and reflection. Time in Egypt, Spain, Turkey, Brazil, Peru, and Cambodia led to fresh insights, major revisions, and expansions of many entries-for example, Tutankhamun, Pol Pot, Dilma Roussef, and Fujimori. Visits to Rome in 2013 and 2014, followed by reading Mary Beard's SPQR: A History of Ancient Rome (London: Profile, 2015), fed my obsessions about the Caesars, the papacy, early church architecture, and Caravaggio, resulting in significant revision and expansion of many entries. Similarly, nine days in Iran in 2015 led to a reconsideration of Ferdowsi, Hāfez, Sa'di, Rumi, Omar Khayyam, al Ghazāli, and the Shi'ite/Sunni schism. Access to Nobel Prize archives provided insight into the selection (and rejection) process. Time in Bourges, Chinon, Blois, and Canterbury led to rethinking about Jacques Coeur and early capitalism, Eleanor of Aquitaine, the Dukes of Guise, Thomas Becket, and Geoffrey Chaucer; rereading Homer, Dante, Dostoevsky, Tolstoy, Proust, and Joyce demanded expanded entries, as did deep exposure to Shakespeare, Beethoven, Wagner, and Mahler.

Dramatic changes in 2016, including the Brexit vote in the United Kingdom and Donald Trump's election as president of the United States of America, led to significant rethinking and revision, especially the significance of the rise of populism and hostility to globalism. Visiting New Zealand in 2017 gave me the opportunity to see Richard Serra's great sculpture Te Tuhirangi Contour and inspect Sir George Grey's astounding collection of medieval manuscripts. That led to revision of entries on Grey and Serra. Since turning 85 my writing and revision for the DWB has been stimulated by a sense of urgency, with time running out.

In comparison to national dictionaries of biography, my attempt has been an overview, analogous to what H. G. Wells had attempted, if that does not sound too pretentious, admittedly limited by my lack of expertise in some areas and remoteness from primary sources, but fortified by the (small c) creator's knowledge and experience. The DWB makes no pretence at objectivity, but it aims at accuracy, so far as possible. 


\section{Living and the Dead?}

I always intended to include entries on the living in my $D W B$. When I finished my first draft in 1959, while Hitler, Mussolini, Tojo, Franklin Roosevelt, and Josef Stalin were dead, Churchill, de Gaulle, Chiang, Eisenhower, MacArthur, Tito, and Zhukov were still alive. It would have given a very lopsided account of World War II and the postwar world to have eliminated the quick in favour of the dead. Postponing treatment of subjects still living, and presumably not eager to be eligible, gives future biographers space and time to reflect instead of rushing to judgment. Presumably any attempt to institute a major international biographical reference work would founder if the living were to be included (think Donald Trump and Vladimir Putin). I had no such inhibition with my $D W B$ and emphasised linkages between past and current subjects. Publishing serious entries on the living may inhibit discussion of sensitive issues such as sexuality, mental and physical health, addictions and obsessions, or financial links, and much primary source material will be inaccessible or embargoed. Inevitably, not having a cut-off date means that I need to check recent deaths or changes in status and attempt some revision. (Less than an hour before writing this paragraph I noted that ex-king Michael (Mihai) of Romania had died in December 2017, unremarked in the Australian press. This will require some attention.)

\section{Wikipedia and the Digital Revolution}

The information technology revolution has been described as a 'digital hurricane'. Reference books were early victims. The creation of Wikipedia, by Jimmy Wales and Larry Sanger, completely transformed reference publishing: few hard- or soft-cover references survived. Wikipedia went online in January 2001 and is available, free, in 292 languages, with 5.3 million entries and 2.8 million biographies (many of them 'stubs'). So there is already a dictionary of world biography of unparalleled scope, available for free on a screen near you, written by enthusiasts, but checked and challenged by readers. There are claimed to be 27,842,261 'registered editors', suggesting an average of five for each entry. Nature examined Wikipedia's science entries and concluded that they were almost 
as accurate as Encyclopedia Britannica. ${ }^{2}$ While the opportunity for fake and distorted entries exists, so does opportunity for immediate challenge and correction. However, Wikipedia will be a major disincentive to embarking on a very large, expensive project on world biography, written by professional scholars.

In the Times Literary Supplement, Peter Thonemann commented that 'Wikipedia does just fine at uncontroversial factual information, but as soon as a topic demands critical discrimination or a bit of intelligent digging, its quality control goes completely haywire. ${ }^{3}$ He points out that 'none of the major British reference works - the $O E D$, the $D N B$ [now ODNB], Grove [The New Grove Dictionary of Music and Musicians], Encyclopedia Britannica - began life within the academy, though some have ended up there'. ${ }^{4}$ The same comment could be made about my Dictionary of World Biography. Jack Lynch, in his admirable You Could Look It Up: The Reference Shelf from Ancient Babylon to Wikipedia, comments: 'Wikipedia, despite being non-commercial, still poses many of the dangers of a traditional monopoly, and we run the risk of living in an information monoculture'. ${ }^{5}$ When I check a reference, it can be disconcerting to find in Wikipedia that I am the reference myself.

\section{Language}

My $D W B$ has an inevitable bias towards the Anglophone world. It is the principal world language, virtually all my readers will have English as a first or second language, and the sources used in my research will have been overwhelmingly published in the United Kingdom, the United States, or Australia. And my own experience outside Australia is predominantly in Europe, then in the United States, and-far behindAsia, South America, and Africa. Of the 30 longest entries in the DWB, 10 are of English-speaking subjects (Shakespeare, Franklin Roosevelt, Lincoln, Churchill, Joyce, Dickens, Ford, Cromwell, Washington, Margaret Thatcher), seven German (Wagner, Mozart, Bach, Beethoven,

2 Jim Giles, 'Internet Encyclopaedias Go Head to Head', Nature 438 (15 December 2005): 900 901, accessed 12 December 2018. doi.org/10.1038/438900a.

3 Peter Thonemann, 'The All-Conquering Wikipedia', Times Literary Supplement, 25 May 2016, accessed 18 October 2018, www.the-tls.co.uk/articles/public/encyclopedic-knowledge/.

4 Thonemann, 'All-Conquering Wikipedia'.

5 Jack Lynch, You Could Look It Up: The Reference Shelffrom Ancient Babylon to Wikipedia (New York and London: Bloomsbury, 2016), quoted in Thonemann, 'All-Conquering Wikipedia'. 
Hitler, Goethe, Marx), three Italian (Michelangelo, Dante, Columbus), two each are French (Napoleon, Proust), Russian (Tolstoy, Stalin), and Spanish (Picasso, Cervantes), and one each is Greek (Homer), Aramaic (Jesus), Chinese (Mao), and Hindi (Gandhi). In recent editions of the $D W B$ I have made significant changes in the names for entries, moving away from or adding to the familiar Anglophone versions to the spelling in the original language, or, with Chinese entries, the nearest equivalent, for example Samuel (Shmu'el), or Jinnah, Muhammad Ali (originally Mahomedali Jinnabhai) or Yongle ('perpetual happiness': personal name Zhu Di).

\section{Gender Bias}

As with other reference books, women are scandalously underrepresented in the $D W B$, due to their historic exclusion from major areas of activity, such as science or politics. Exceptions have been saints (Mary, Catherine, Teresa, Frances, Elizabeth), rulers (Hatshepsut, Cleopatra, Elizabeth I, Maria Theresia, Catherine the Great, Victoria, Cixi), writers (Sappho, Aphra Behn, Jane Austen, George Sand, Emily Dickinson, George Eliot, Agatha Christie, Simone Weil, Iris Murdoch, Oodgeroo Noonuccal, Judith Wright, Tony Morrison, Hilary Mantel), artists (Angela Kauffman, Louise Bourgeois, Georgia O’Keeffe, Barbara Hepworth, Bridget Riley), musicians (Hildegard of Bingen, Clara Schumann, Melba, Sutherland, Ferrier, Callas, Argerich), actors (Greta Garbo, Edith Evans, Grace Kelly, Catherine Deneuve, Cate Blanchett), or dancers (Pavlova, de Valois, Fonteyn, Ulanova). Later, female politicians and scientists gained international recognition, but it was a slow process: Eleanor Roosevelt, Jiang Qing, Eva Peron, Margaret Thatcher, Theresa May, Angela Merkel, Hillary Clinton, Julia Gillard, Marie Curie, Dorothy Hodgkin, Rosalind Franklin, Rosalyn Yalow, Elizabeth Blackburn, and Fiona Stanley are among the exceptions. Of my 30 longest entries, only one (Thatcher) is female. She played a very significant role in ending the bipartisan consensus in British, and, later, world politics. Angela Merkel is an admirable and courageous figure but her impact has been less. I estimate that women take up barely 15 per cent of the DWB's length. Chambers Biographical Dictionary has a higher proportion of female entries because of its emphasis on contemporary entertainers and athletes, such as the Spice Girls, Amy Winehouse, and the controversial ice-skater Tonya Harding. 


\section{National Bias}

Of my 30 longest entries, five are German, five English, four American, three Italian, two each French, Spanish and Russian, one each Greek, Austrian, Chinese, Indian and Irish, with Jesus and Marx too hard to classify. I was careful about the relative balance of entries. Certain categories were automatically included: all the Roman Caesars, most Holy Roman Emperors, all British sovereigns and prime ministers, French kings and presidents, United States presidents, and prime ministers of Canada, Australia, New Zealand, India, and South Africa (presidents after 1984). Of the 266 Popes, I have included more than 60: all who held the papal tiara since the eighteenth century, and earlier Popes who left a lasting influence. The numbers of entries on Jews, Irish, Scots, and Hungarians, despite their relatively small populations, reflect their exceptional contributions to music, literature, philosophy, mathematics, physics, medicine, and engineering. Inevitably, Israel and Ireland had and have a disproportionate political and cultural significance globally, with more representation in the $D W B$, say, than the more populous New South Wales and Victoria.

I tried to be careful not to overload the $D W B$ with Australians. If I included a contemporary Australian poet or composer, should there be a Canadian of equal standing? The intention was to keep some balance but I may have overdone it. It is striking how many Australians are included in the Chambers Biographical Dictionary, many of whom I would not have chosen. However, Chambers omits some major figures: Redmond Barry, Peter Lalor, the Myer family, Herbert Vere Evatt, Essington Lewis, Edward 'Weary' Dunlop, Phillip Law, Frank Fenner, Donald Horne, Don Dunstan, John Olsen, Brett Dean, William Deane, Michael Kirby, Gareth Evans, Peter Singer, and Tim Winton.

\section{Contemporary and Political Bias}

It was inevitable that there would be some bias in entry selection towards the twentieth and twenty-first centuries - the lifetime of my readers, reflecting their desire for information to understand the context of how we live now, the impact on politics, revolutions, ideology, technology, science, World Wars I and II, the Cold War, literature, art, film, music, and media. Of my 30 longest entries, 11 subjects were active in the 
twentieth or twenty-first centuries. I have made some attempts to write about The Beatles, who have had (I am told) a continuing influence. Despite my long (and increasingly unhappy) career in politics, I tried to be clinically detached in my entries on public figures, and would immodestly point to entries on Harold Macmillan, Margaret Thatcher, and Richard Nixon. However, I have not disguised my loathing of totalitarian systems, whether Left or Right, and entries on Hitler, Stalin, Mussolini, and Mao are obvious examples. I felt that my explanation of ideologies was a strength and over many years I have tried to cover my areas of weakness, such as sport, popular music, ballet, ornithology, gardening, and fourteenth-century Islamic tiles.

\section{Proportionality}

The latest edition of my $D W B(2018)$ has the equivalent of 920 full pages of text, more than 8,000 entries, and 840,000 words. Four factors determined entry length: likelihood that the entries would be frequently consulted, availability of resource material, degree of influence that the subjects exerted on how we live (language, theatre, catharsis, humour, tragedy, and so on), and the extent of cross-referencing to other subjects in the $D W B$. Thus, Shakespeare is by far my longest entry. Of the 30 longest entries in the $D W B$, nine are of writers, 12 political leaders, four composers, two artists, and one each are religious (Jesus), political philosopher (Marx) and manufacturer (Ford). It is a matter for regret that only Jesus, Mao, Gandhi, and possibly Homer were not of European ancestry, and that reflects the cultural biases that influence me and my potential readers. I try to compensate, but it is a formidable task.

The Merriam-Webster entry on William Shakespeare covers his life in nine lines ( 94 words), followed by a list of plays and dates, making 29 lines (single column) in total. Chambers devotes two full pages to Shakespeare, the second mostly a chronological list, about 2,000 words in total. My Shakespeare entry has 2,386 words, with 56 cross-references (indicated by ${ }^{*}$ ), emphasising his life, his sources, the context of his work in the times of Elizabeth I and James I, and his influence on later writers, as well as including a bibliography. Thirty-seven plays are referred to, but in context, not set out in tabular form. 


\section{The Chambers Case Study}

Chambers Biographical Dictionary is in direct competition with my $D W B$, so I can hardly claim objectivity. Nevertheless, I am puzzled by its contents and have failed to coax Chambers's editors to explain their rationale. Chambers has serious problems of balance and proportionality, being variable, and often weak, in politics, literature, music, painting and sculpture, architecture, science and technology, and exploration. It is exceptionally strong in sport, film and television, and pop music and other performing arts, including murder. Murderers are well represented: Ted Bundy, Rosemary and Fred West, Ruth Ellis, James Hanratty, John Christie, Albert Desalvo, Edith Thompson, Myra Hindley, Peter Sutcliffe, Peter Manuel, and Donald Neilson, but not the American terrorist Timothy McVeigh. Many of its subjects are famous for being famous.

Chambers operates at three levels: serious, popular, and local. There are significant numbers of subjects, some quite lengthy, who appear to have been included only because, until 2009, Chambers operated from Edinburgh. Classic examples are retired newspaperman Sir Alastair Dunnett and his wife Dorothy, with 32 lines between them. Sir Alastair was 'intensely committed to his native country' and 'served ... on the board of several national bodies'. ${ }^{6}$ Lady Dunnett was a member of the Scottish Society of Women Artists, and has written several novels. Good for them, but who outside Edinburgh will look them up?

The longest entries in Chambers are Shakespeare, Hitler, Mozart, Dickens, Scott, Napoléon, Wagner, Mary Queen of Scots, Jesus, and the Wesleys. Margaret Thatcher is well ahead of Winston Churchill or Elizabeth I of England (not to mention Elizabeth I of Australia). George Washington has the longest entry for any United States president, followed by Abraham Lincoln and Ronald Reagan. The Dunnetts are slightly behind Franklin D. Roosevelt but well ahead of Jefferson, Madison, or Monroe. Four central figures of the second Industrial Revolution-Edison, Bell, Ford, and Marconi-have very short entries in Chambers. Elton John's entry is longer than Gustave Flaubert's, and the poet Ted Hughes has more than Keats, Kafka, Proust, Pound, Joyce, or Beckett.

6 Chambers Biographical Dictionary, 9th ed. (London: Chambers Harrap Publishers, 2013), 465. 
Australia is well represented, suggesting a zealous national working party without central direction. There are surprises. Elizabeth Evatt, a distinguished judge and campaigner for social change, is there, rightly, but not her eminent and controversial uncle Herbert Vere Evatt, who was a historian, Australia's youngest High Court judge, minister for external affairs and attorney-general, an architect of the United Nations, president of the UN General Assembly, Labor leader, central figure in the Australian Labor Party split (1954-55), chief justice of New South Wales, and the subject of five biographies. Judith Wright, poet and environmentalist, has a longer entry than the Wright brothers. Ita Buttrose, the journalist, publisher, and broadcaster, has slightly fewer words than Michel de Montaigne but more than President Woodrow Wilson. In Chambers 2013 edition many Australian athletes and entertainers, including Rolf Harris, are there but seven prime ministers are missing: Chris Watson, Joseph Cook, James Scullin, Earle Page, Frank Forde, John McEwen (admittedly, the previous three only for short periods), and Julia Gillard. (Tony Abbott was elected later in 2013 and Malcolm Turnbull displaced him in 2015.) The Australian soprano Nellie Melba (née Helen Porter Mitchell), the pride of Melbourne, and of Scottish descent, has more words in her entry than Palestrina, Monteverdi, Telemann, Händel, Haydn, Rossini, Berlioz, Chopin, Liszt, Bruckner, Brahms, Dvořák, Puccini, Mahler, Debussy, Richard Strauss, Sibelius, Rachmaninoff, Ravel, Bartók, or Stravinsky. Even odder, her entry exceeds the length of Franklin and Theodore Roosevelt combined, and is more than Homer, Muhammad, Galileo, Columbus, Cervantes, Velázquez, Goya, Dostoevsky, or Einstein. They shook the world; she had a lovely voice.

Chambers has a foreword, not by a scholar but by a television presenter, Dame Jane Bakewell, who begins: 'I'm always alarmed when people tell me that there are more individuals alive on the planet right now, than the sum total of all those who ever lived throughout history.? (The punctuation is presumably hers.) She is right to be alarmed, but it simply is not true. The current estimate of world population is 7.4 billion: credible estimates of total population throughout history are in the range of 95 to 105 billion. That Chambers begins with such a serious error is a concern. Has this delusion shaped the selection of names with its emphasis on the twentyfirst century? It may have been a marketing strategy too, emphasising the second Elizabethan era rather than the first. 


\section{Conclusion}

The DWB means a great deal to me because I have poured more into it, over a longer period, than any other work. Sleepers, Wake!: Technology and the Future of Work (Oxford University Press, 1982) was my most important book, a textbook for a generation, and having some impact in China and Korea: a prophetic work in some ways. But many of the ideas that I wrote about which seemed wild speculation (people having handheld computers, for example) are now a central factor in contemporary life. But my $D W B$ is a guidebook for the abundant life and I am touched by the number of couples who say that they take turns in reading it to each other. They value the book-and here some immodesty bursts out-because they hear my voice, detect my enthusiasms, and value its authenticity (and accuracy, I hope). 
This text is taken from 'True Biographies of Nations?': The Cultural Journeys of Dictionaries of National Biography, edited by Karen Fox, published 2019 by ANU Press, The Australian National University, Canberra, Australia.

doi.org/10.22459/TBN.2019.10 